\title{
The Dependence of Didactic Games on Physics in the Preparation of Technical Engineers and its Competence Approach
}

\author{
Docent U. Sultonova, B. Amanov ${ }^{\# 1,}$ Docent N..T. Kadyrova ${ }^{\# 2,}$ Assistant Sh. Khakberdieva ${ }^{\# 3,}$ \\ Assistant M. Boboeva ${ }^{\# 4}$ \\ Termez branch of Tashkent State Technical University, Termez city, Uzbekistan ${ }^{\# 1}$ \\ Tashkent Pharmaceutical Institute, Tashkent city, Uzbekistan ${ }^{\# 2}$ \\ Termez city, 4 - Economics Boarding School teacher, Termez city, Uzbekistan ${ }^{\# 3}$ \\ Termez State University, Termez city, Uzbekistan ${ }^{\# 4}$ \\ jakhongirshaturaev@gmail.com / j.irelations@gmail.com
}

\begin{abstract}
Developing students' creative thinking, developing their mental abilities, is the most important psychological and pedagogical challenge in teaching physics. This requires the widespread use of active teaching methods, non-traditional forms of education and training, and the study of the interaction of bodies and phenomena with their movement and development. It is especially important for students to increase their game activity, to acquire new knowledge, to form and develop their knowledge and skills, and to enhance the effectiveness of physics study in general. Consequently, a system has been developed and developed to enable students to develop their personal and professional competence as a result of education, creating the necessary conditions for the full development of students at various stages of continuous education.
\end{abstract}

Keywords: didactic games, physics, technical engineers, competence approach, psychological and pedagogical challenge, enhance physics, knowledge and skills.

\section{INTRODUCTION}

At present, the strategy of action for further development of the Republic of Uzbekistan is based on the five important initiatives adopted by the President: "Further improvement of the system of continuous education, enhancing opportunities for quality education services, and prepare future technical specialists on the basis of a competence-based approach identified as a task the creation of the ash, innovation, physics, science competence approach to the development of the methods of teaching and practice on the basis of actual significance.

\section{Method AND Materials}

Objectives: The world education system is designed to develop and improve teaching methods and mechanisms in the field of physics based on modern development principles, based on the trends of world development, based on the evaluation and implementation of pedagogical innovation and training of competitive research personnel. Increasingly, our society is essential to its development in line with world civilization. The role of physical science in the world in human life, the creation of appropriate conditions for the life of all citizens living in our country, in the training of technical personnel in higher education institutions, especially in technical universities, in practical technological and pedagogical processes professional self-activation, non-standard solutions should be particularly important to the campaign.

In addition to studying and working throughout one's life, he also participates in games. In human life, games play the following functions

Functions such as entertaining (inspiring, motivating)

- Communicative dialogue

- Throughout the game, humanity demonstrates its practical identity

- Game Therapy: Overcoming Different Challenges

-Different: During the game, students will be shown features, opportunities

- The active and creative activity of this activity is a high level of activity, competitive competitions, contests.

It is worth noting that didactic games are fundamentally different from business, games. Didactic game preparation phase: The purpose of the lesson, the description of the problem under study, the objectives, the justification of the tasks, the game plan, the context of the situation. Carrying out stages: Work with resources, training, mental attack, team exit, protection of results, discussion rules. Analysis and Summary Stage Selfevaluation, conclusions and summaries, recommendations. Training games provide students with the ability to work independently, develop creative thinking and team management, decision-making, and analysis and development. During the game the following skills and competences are formed: 
- Decision-making, gathering and analyzing relevant information

- Decision-making in conditions of inadequate and reliable information.

- Analyze specific issues

- Teamwork, teamwork, and collaborative decision-making

- Creative use of a systematic approach to process and event research

It is necessary to introduce professional competence, organizational and communicative competence, professional self-appraisal competence in the field of professional orientation, intellectual independence in any field of professional activity, which can be used for function and formation and development of various psychological characteristics and qualities of a person. For teachers, didactic games are a labor-intensive type of preparation, and their willingness to host them through a deep understanding of the learning process. Games have one undeniable advantage over other teaching methods:

- Ensure that the knowledge gained is put into practice

- One-time games have been used effectively for a number of years

- Creating students' competencies is a powerful tool for engaging content

- Provide students with the ability to demonstrate research methodology

Problems: Issues are seen as the priority of individual traits in group decision-making. Distribute the rights and responsibilities of teachers and students during the game to content and time in a particular sequence of steps. The effectiveness of the game as a method of teaching depends on the logistics rather than the conventional method, which depends on the special equipment of the game, the computers and the number of participants. Another problem is the objective assessment of each player, and discussion of the conclusion is important. The positive emotion created by students during didactic games will keep them from becoming tired. Increases their intellectual abilities. The general issues of using didactic games in the process of teaching physics, although widely covered in scientific and methodological literature, are focused on problem solving and laws. However, it is natural for students to learn physics is very difficult and requires unconventional approaches to solving some of their problems. There are a number of scientific, theoretical, methodological, and didactic reasons for this. Therefore, the teaching of physics requires the use of new pedagogical technologies, unconventional methods and forms. In particular, didactic games help students to develop their own thinking, ingenuity, diligence, responsiveness, ability to make logical conclusions, to work on themselves, to compare known and unknown aspects, and to reflect on existing knowledge. We give examples of didactic games in the study of physics on the topic, in lessons and in circles on the organization of independent work of students. It is advisable to use textbooks and additional literature to achieve high performance in these didactic games.

Physical dictionary game: The student writes a single letter on a blackboard, and students write their own notebooks, which include the physical term, physical size, physical instruments, units, and so forth. He then tells the reader how many words he has written. The teacher goes around to check, and the one who writes the most, the student gets the championship. The words that the student has found, and the words that are not in the students who have been left behind, are written on the blackboard, and all students copy the words they couldn't find on the blackboard. For example, the letter T is words such as speed, sound, nature, brake, vibration, temperature, thermodynamics, Thomson, Tesla, fusion, accelerator, fullness, gravity, transistor, transuranic, turbulent, smoke, wave, flat acceleration, flat acceleration. Physio meters on auxometers, amorphous, atomic, Avogadro, acoustics, alpha, antimony, atmospheric, astrophysical, aluminum, adiabatic, eternal, ground, angstrom, aneroid, aerometer, ampere meter, absolute elongation, amorphous, anisotropic, circular, etc. The domino game continues as follows:

$$
\begin{aligned}
& \mathrm{v}=\frac{\mathrm{s}}{\mathrm{t}} \rightarrow \mathrm{t}=\frac{\mathrm{s}}{\mathrm{v}} \rightarrow \mathrm{V}=\mathrm{v}_{0}+\mathrm{at} \rightarrow \mathrm{t}=\frac{\mathrm{v}-\mathrm{v}_{0}}{\mathrm{a}} \rightarrow \mathrm{a}=\frac{\mathrm{v}^{2}-\mathrm{v}_{0}^{2}}{2 \mathrm{~S}} \rightarrow \mathrm{s}=\mathrm{v}_{0} \mathrm{t}+\frac{\mathrm{at}^{2}}{2} \rightarrow \mathrm{t}=\frac{\mathrm{A}}{\mathrm{N}} \rightarrow \mathrm{N}=\frac{\mathrm{A}}{\mathrm{t}} \\
& t=\frac{A}{I U} \rightarrow U=I R \rightarrow R=\rho \stackrel{\mathrm{s}}{\rightarrow} S=\frac{\mathrm{F}}{\mathrm{P}} \rightarrow P=n k T \rightarrow T=\frac{2 E_{K}}{3 \mathrm{~K}} \rightarrow k=\frac{R}{N_{A}} \rightarrow N_{A}=\frac{N}{v} \rightarrow v=\frac{m}{\mu} \rightarrow \mu=m N_{A} \rightarrow \\
& \rightarrow N_{A}=\frac{N R T}{P V} \rightarrow T=\frac{P}{n K} \rightarrow k=\frac{2 E_{K}}{3 T} \rightarrow T=\frac{P}{n K} ; n=\frac{N}{V} \rightarrow V=\frac{m}{\rho} \rightarrow \rho=\frac{m}{V} \rightarrow V=S h
\end{aligned}
$$

Physical linguistics: Linguistics deals with language laws, speech charm. The language of physics is very rich, and the appropriate use of its capabilities can greatly enhance students' knowledge. Different physical sizes, laws, and puzzles related to units teach students to be fluent, resourceful, and responsive. This event, first and foremost, encourages them to work independently, gain additional knowledge, and use the physical and written skills of physics.

When you find the correct answers to the following questions and place their initials on empty cells, one of the words comes from the wisdom that will keep students in mind that physics is a powerful natural science.

Assignment: When you find the correct answers to the following questions and place them in blank cells that contain the initials, one of the words comes from the mind, which reminds the students that physics is a powerful natural science. 


\begin{tabular}{|l|l|l|l|l|l|l|l|l|l|}
\hline 1 & 2 & 3 & 4 & 5 & 6 & 7 & 8 & 9 & 10 \\
\hline $\mathrm{F}$ & $\mathrm{I}$ & $\mathrm{Z}$ & $\mathrm{I}$ & $\mathrm{K}$ & $\mathrm{A}$ & $\mathrm{F}$ & $\mathrm{A}$ & $\mathrm{N}$ & $\mathrm{I}$ \\
\hline
\end{tabular}

\begin{tabular}{|l|l|l|l|l|l|l|l|l|l|}
\hline 11 & 12 & & 13 & 14 & 15 & 16 & 17 & 18 & 19 \\
\hline $\mathrm{M}$ & $\mathrm{U}$ & $\mathbf{}$ & $\mathrm{J}$ & $\mathrm{I}$ & $\mathrm{Z}$ & $\mathrm{A}$ & $\mathrm{L}$ & $\mathrm{A}$ & $\mathrm{R}$ \\
\hline
\end{tabular}

\begin{tabular}{|l|l|l|l|l|l|l|}
\hline 20 & 21 & 22 & 23 & 24 & 25 & 26 \\
\hline $\mathrm{M}$ & $\mathrm{A}$ & $\mathrm{Y}$ & $\mathrm{D}$ & $\mathrm{O}$ & $\mathrm{N}$ & $\mathrm{I}$ \\
\hline
\end{tabular}

1. Objects made up of various substances are called

2. The object may move so that the line connecting the two points of its voltage is parallel to itself even when the body is moved is called movement.

3. The mass of a substance per unit volume is

4. The velocity of the body after the termination of the effect of another body on one body is called

5. The effect of one body on another is called

6. Instrumentation for acceleration

7. An expression of a quantitative link between the dimensions that characterize events is called

8. A body immersed in a liquid squeezes a fluid of its own size and is subjected to the force of this magnitude ..........

9. Power Unit

10. The amount of energy transferred to the body by heat exchange is called

11. Physical size characterizing the inertia of the objects

12. Passing through the center of the lens

13. Father of Russian aviation

14. The chaotic behavior of the molecules that make up the body and the sum of the interacting energies of the molecules are called

15. What unit of physical size is $\mathrm{kg} / \mathrm{m} 3$ ?

16. Intensity Measurement Tool

17. Size unit

18. The pushing force on a body immersed in liquid or gas One of the optical instruments

19. A fluid or a solid body of properties

20. Size of trajectory length

21. Changes in the shape and size of the body under the influence of force.

22. The velocity of the trajectory at a particular time and at a particular point called velocity.

23. Power unit capable of accelerating $1 \mathrm{~m} / \mathrm{s} 2$ per $1 \mathrm{~kg}$ mass

24. The force formed by the sliding of one object on the surface of another and the opposite direction of motion is called

Answers:

1. The physical body. 2. Moving Progress. 3. Density. 4. Inertia. 5. Strength. 6. Accelerometer. 7. Physical regularity. 8. Archimedes power. 9. Newton. 10. Heat volume. 11. Mass. 12. Read on. 13. Zhukovsky. 14. Internal energy. 15. Density. 16. Aerometer. 17. Lit. 18. Archimedes power. 19. Richag. 20. Microscope. 21. Amorphous. 22. Path. 23. Deformation. 24. Instantaneous velocity.

Physical puzzles: The puzzles are intertwined with human, social, and natural phenomena and are always based on real ground. It reflects various things in the material world around us. The riddle will help young people to develop their thinking skills, teach them to express a particular idea in artistic style, and to be more attentive, ingenious, and develop self-sustaining competencies.

Listen, friend, By the way, a poetic puzzle. One breath of thought, Just find a rhyme.

According to what she has earned, I say to everyone, congratulations!

Regarding solids pressure 
1) There were two knives, 2) teeth that are not alive;

Every time they stand together. He does not eat or drink.

What they do is good. If they walk away. Looks like scissors.

Only then will the master work,

Knitting clothes. The curve bites the nail. Now, think about it, known for its service,

Easy, it's ...... (scissors) Her name... (repository)

Regarding light and heat phenomena.

(1) The sword that I had taken from it went green. (Morning light); 2) The light is hot and my eyesight is tight. (Sun)

3) The double lamp is facing the guard. (Eyes, eyelashes)

\section{Electro technical}

1) The sword on the top shines; Cociluts are roaring. (GES)

2) One pear hung on the house; It was bright everywhere. light bulb

3) Underneath, cap on the head, Look under the hood. (table lamp)

Numbers and pointers are used to perform the puzzle. An indicator in front of the numbers indicates the first direction in the answer, i.e. the initial two or three letters in the scientist's name. The learner chooses the course to determine the remaining letters. In later cases, you can change the direction up, down, right and left. For example, to determine the answer to the fourth question, two cells in the index move to the right to identify the letters $\mathrm{P}$ and $\mathrm{E}$, and then the reader selects the remaining directions to form the word Rezerford. Table 2.1.

A puzzle to give information about physical scientists

\begin{tabular}{|c|c|c|c|c|c|c|c|c|c|c|}
\hline $1 \rightarrow$ & $\mathrm{N}$ & $\mathrm{Yu}$ & $3 \rightarrow$ & $F$ & A & D & $E$ & $\mathrm{Y}$ & $7 \rightarrow$ & $\mathrm{E}$ \\
\hline $\begin{array}{l}6 \\
\downarrow\end{array}$ & $2 \rightarrow$ & $\mathrm{T}$ & $\mathrm{O}$ & $\mathrm{N}$ & $\mathrm{R}$ & A & $4 \rightarrow$ & $\mathrm{R}$ & E & $\mathrm{R}$ \\
\hline $\mathrm{E}$ & $\mathrm{Y}$ & $\mathrm{N}$ & $\mathrm{R}$ & I & $\mathrm{CH}$ & $\mathrm{E}$ & $\mathrm{L}$ & $\mathrm{E}$ & $Z$ & $\mathrm{C}$ \\
\hline $5 \rightarrow$ & $\mathrm{B}$ & SH & $\mathrm{T}$ & $\mathrm{E}$ & $\mathrm{Y}$ & $\mathrm{N}$ & $\mathrm{L}$ & I & $\mathrm{E}$ & $\mathrm{T}$ \\
\hline $\begin{array}{l}8 \\
\downarrow\end{array}$ & $\mathrm{O}$ & L & TS & $\mathrm{M}$ & A & $\mathrm{N}$ & A & B & $\mathrm{R}$ & E \\
\hline B & $\mathrm{E}$ & $\mathrm{R}$ & $\mathrm{I}$ & $\mathrm{L}$ & $9 \rightarrow$ & $\mathrm{E}$ & $\mathrm{Y}$ & $\mathrm{V}$ & $\mathrm{F}$ & $\mathrm{D}$ \\
\hline $10 \rightarrow$ & $\mathrm{G}$ & $\mathrm{N}$ & $\mathrm{U}$ & $\mathrm{L}$ & $12 \rightarrow$ & $\mathrm{CH}$ & $X$ & G & $\mathrm{O}$ & $\begin{array}{l}13 \\
\downarrow\end{array}$ \\
\hline $\begin{array}{l}11 \\
\downarrow\end{array}$ & E & $\mathrm{R}$ & $\mathrm{S}$ & $\mathrm{L}$ & E & E & E & D & $\mathrm{R}$ & $\mathrm{P}$ \\
\hline $\mathrm{K}$ & $\mathrm{E}$ & $\mathrm{P}$ & $\mathrm{R}$ & $\mathrm{N}$ & B & $\mathrm{D}$ & $\mathrm{N}$ & $\mathrm{O}$ & $\mathrm{D}$ & A \\
\hline $14 \rightarrow$ & A & $\mathrm{L}$ & $\mathrm{E}$ & $\mathrm{K}$ & $\mathrm{P}$ & $\mathrm{V}$ & $\mathrm{V}$ & A & $\mathrm{L}$ & $\mathrm{S}$ \\
\hline $15 \rightarrow$ & $\mathrm{R}$ & E & $\mathrm{N}$ & S & $\mathrm{D}$ & I & K & $\mathrm{SH}$ & $\mathrm{CH}$ & K \\
\hline $\mathbf{M}$ & $\mathrm{N}$ & $\mathrm{O}$ & $\mathrm{T}$ & A & $\mathrm{N}$ & $\begin{array}{l}16 \\
\downarrow\end{array}$ & $\mathrm{R}$ & $\mathrm{U}$ & Y & A \\
\hline $\mathbf{P}$ & $\mathrm{J}$ & Z & G & E & $\mathrm{N}$ & B & E & $\mathrm{N}$ & I & $\mathrm{L}$ \\
\hline
\end{tabular}

III. SCIENTIFIC AND PRACTICAL SIGNIFICANCE

The educational games give students the skills to work independently, creative thinking and team management, decision-making and analysis, development and strengthening. The following skills and competencies will be generated during the game:

- Decision-making, gathering and analyzing relevant information.

- Decision-making in conditions of inadequate and reliable information.

- Analyze specific issues.

- Teamwork, developing collaborative solutions using group thinking.

- Creative use of a systematic approach to process and event research.

- Ensure that the knowledge gained is put into practice. 
- One-time games have been used effectively for a number of years.

- Formation of comets in students is a powerful tool to stimulate the content of the activity.

- Provide students with the ability to demonstrate research methodology.

- Problems are seen as the priority of individual traits in group decision-making.

The high efficiency of the game teaching method differs with the significant advantages compared to the traditional method. Here are some of them:

- Accuracy of the decision result.

- Controls the time scale of the variability of time.

Game situations form the basis of a game program and include a detailed description of it.

\section{RESULTS}

Organizational and communicative qualities, creative self-determination of professional competence, intellectual independence in a particular area of professional activity, which can be used to function and to develop and develop various psychological characteristics and qualities of a person. It is necessary to introduce evaluation functions. Didactic game lessons The first-year students of Nizami Tashkent State University, Termez State University, Karshi State University held open lessons and interesting parties, introduced a set of didactic games and determined the effectiveness of the university students in physical education. The development of Termez State University - 89\%, Tashkent State University named after Nizami - 81\%, Karshi State University - 79\%. Students achieved a high level of proficiency through didactic games using a competency approach to physics, and a textbook on "Technology of Didactic Games" in physics was developed and published. It was popularized in the country and introduced into the educational process and the club activities.

\section{CONCLUSION}

The learning process in the classroom and club activities was combined with the activities of the game and the competition. Such training was called didactic play and the following conclusions were reached.

During training:

- Demand based on mutual trust;

- to organize the educational process effectively and to stimulate the interest and motivation of students;

- encouraging students to collaborate on learning;

- use of new technologies related to the organization of independent learning activities. These technologies also include didactic gaming, problem-based learning, collaborative learning technologies. Didactic gaming technologies are used in the form of didactic gaming lessons.

Throughout the course, students perform the following tasks:

1. Through the game, students' interest in a particular activity grows.

2. It gives the reader a chance to express their interest, knowledge and self-esteem.

3. Prepares the student to cope with various difficulties in a difficult process.

4. Players will develop a culture of community engagement.

Gaming activities are characterized by 4 features.

- Creation of freelance development activities;

- Creating a creative environment (participants will have relevant creative and independent activities);

- An emotional state (competition, co-operation and mutual support are created during the game);

- Observe the rules of the game.

The structure of the game activities is as follows:

- Determine the purpose of the game;

- Identify ways to achieve this goal;

- Analysis of the obtained results;

The teacher must meet the following didactic requirements for the organization of didactic game lessons or group activities.

1. The educational, educational, developmental goals and objectives outlined in the didactic play lessons should be addressed.

2. Arrange the game structure in a certain sequence.

3. Great results need to be spent in less time. 
Correct organization of students' competence-based educational activities Self-development as a person through the analysis of their own activities Self-development and awareness of socially active civil science and technology competencies the scientific methodological system and recommendations obtained are summarized, tested and applied presented. Didactic games have enhanced the ability of physical puzzles to enhance students' interest in learning, and have developed and implemented appropriate methodological recommendations in this regard.

\section{RECOMMENDATIONS}

The competence of developing independent creative worksheets for the study of design experimental learning materials in the course of physics training of future technical engineers. Effective organization of independent work at home and outside the auditorium facilitated the theoretical and practical significance of the development of self-control competence in developing independent thinking competencies. Experimental tests were analyzed using a competence approach to the physics. The competence-based approach has shown that non-traditional methods of teaching physics are more effective than traditional ones, and the results confirm the effectiveness of the experimental tests and the validity of the experimental tests. As a result of the researches and experimental researches the methodology of teaching physics on the basis of competence-based approach was developed and confirmed to increase students' knowledge, methodical recommendations and manuals were developed.

\section{REFERENCES}

[1] Babansky Yu.K. Optimization Process Obuchenia. -M.: Pedagogy. 1997. -175 pp.

[2] Babansky Yu.K. Methods of teaching in modern high school. -T.: Teacher. 1990. - 230 p.

[3] Babansky Yu.K. Methodology of teaching physical in elementary school. -M.: Prospecting. $1968-199$ p.

[4] Balash V.A. Problems in physics and methods of their solution. -T.: Teacher. 1966. $-407 \mathrm{~b}$.

[5] Davydov V.V. "Types of conversation in education" - - M.: 1972. - 423s.

[6] Ismailov M. A collection of questions from physics. -T.: Teacher. 1996. - 119b

[7] Nurmatov J., Isroilov MI, Nishonova M. Laboratory work on physics. (Textbook for Academic Lyceums and Vocational Colleges). -T $\therefore$ Teacher, 2002. $-288 \mathrm{p}$.

[8] Shaturaev, Jakhongir. (2019). The importance of handwriting in education. International Journal of Advanced Research. 7. 947-954. 10.21474/IJAR01/10237 http://dx.doi.org/10.21474/IJAR01/10237

[9] Shaturaev, J., 2014. Comparative Study on Similarities and Differences of Teaching and Learning Process in Primary Schools in Indonesia and Uzbekistan (Doctoral dissertation, Universitas Pendidikan Indonesia).

[10] Tojiev M. Modern information technologies in educational process (Methodological aspect). -T.: 2001. $-148 \mathrm{~b}$.

[11] Turdiev N.Sh. Physics: Textbook for 6th grade of general secondary schools. - T .: Cartography. 2005. - 160b.

[12] Turdiev N.Sh. Physics: Textbook for the 8th grade of secondary schools. - T .: Turon Iqbol Publishing House, $2006 .-160 \mathrm{~b} .12$. Tursunmetov KA, Uzoqov AA, Burribaev I. Collection of Physics. -T.: Teacher. 2003. -189 b.

[13] Vinogradova EP Combination Manager in System Requirements Dis... kand.ped nauk.- M .: 2003. - 135 b. 